\title{
EЛEKTPOTEXHIKA
}

УДК 621.316.722.1

DOI https://doi.org/10.32838/2663-5941/2021.2-1/11

\section{Сидоренко О.I.}

orcid.org/0000-0002-3584-4380

Український науково-дослідний інститут спеціальної техніки та судових експертиз

Служби безпеки України

\section{СТАБІЛІЗУЮЧИЙ ПЕРЕТВОРЮВАЧ ЯК ОСНОВА СИСТЕМИ СТАБІЛІЗАЦІЇ ПАРАМЕТРІВ ЕЛЕКТРИЧНОЇ ВИХІДНОЇ НАПРУГИ}

Досліджено принципи роботи стабілізуючих перетворювачів напруги з виведенням функціональних схем за трьома основними типами перетворювачів. Підкреслено, що базовими схемами стабілізуючих перетворювачів напруги є понижувальна та підвищувальна схеми. Зазначається, щзо під час проектування джерел вторинного електроживлення для агрегатів безперебійного живлення й автономних систем електропостачання регулювання (стабілізацію) вихідної напруги необхідно здійснювати в обох вищеназваних зонах. Наведено необхідність застосування приниипів стабілізації для систем автономного електропостачання. Доведено, щуо найбільш перспективним методом регулювання вихідної напруги для широкодіапазонної зміни частоти обертання генератора і споживаної потужності є регулювання напруги в обмотках збудження електрогенератора. Охарактеризовано канали стабілізації вихідної напруги та наголошено, щзо можна використовувати одночасно два або всі канали, щьо дає змогу точно змінювати відсоток амплітудної модуляції і стабілізувати вихідні електричні параметри. Наведено три функиіональні схеми стабілізачії параметрів електричної вихідної напруги з різними видами струму, щзо надходить на стабілізачію: змінного, постійного та комбінованого. Розкрито складові частини кожної схеми окремо. На основі аналізу роботи функиіональних схем зазначено, що відмінність обертання ротора і живильної обмотки асинхронного збудника від автономного інвертора з широтно-імпульсною модуляиією полягає у тому, що електрорушійна сила індукується в обмотиі ротора асинхронного збудника. Доведено, щзо в результаті вилучення вихідної напруги за допомогою иіклоконвертера можна скасувати залежність частоти биття від частоти обертання валу генератора.

Ключові слова: стабілізуючий перетворювач, напруга, електрична енергія, регулювання, джерело живлення, схема, електропостачання.

Постановка проблеми. Перетворювачі електричної енергії у своїй фундаментальній основі мають безліч різних класів, перетворювачі постійної напруги належать до одного з них. Розробленню, вдосконаленню та підвищенню ефективності роботи перетворювачів електричної енергії присвячена велика кількість публікацій, значна частина яких стосується перетворювачів постійної напруги, заснованих на базових схемах: понижувальній і підвищувальній [1]. Саме понижувальна і підвищувальна схеми беруться за основу під час вирішення завдань регулювання (стабілізації) вихідної напруги в одній із двох зон, що знаходяться нижче і вище від рівня напруги джерела живлення.

Інколи під час проектування джерел вторинного електроживлення для агрегатів безперебій- ного живлення й автономних систем електропостачання регулювання (стабілізацію) вихідної напруги необхідно здійснювати в обох вищеназваних зонах. Для цього застосовуються стабілізуючі перетворювачі постійної напруги, які традиційно будуються на основі комбінації з двох згаданих базових типів перетворювачів постійної напруги (комбіновані перетворювачі постійної напруги) або шляхом застосування трансформаторних схем різної складності, включаючи багатоосередкові або дискретні перетворювачі.

Однак через певні недоліки вищеназваних перетворювачів актуальним $є$ завдання побудови стабілізуючого перетворювача з вихідною напругою як вище, так і нижче від рівня напруги джерела живлення, що володіє досить широким діапазоном регулювання і високими динамічними, 
статичними, експлуатаційними і технологічними властивостями.

Останнім часом велика увага фахівців перетворювальної техніки приділяється питанням забезпечення стійкості, поліпшення й оптимізації динамічних властивостей перетворювачів постійної напруги. Ці питання вирішуються шляхом удосконалення методів і механізмів управління перетворювачами, що дає змогу отримати додатковий економічний ефект, найчастіше більший, ніж від застосування самого перетворювального пристрою. У зв'язку з цим питання синтезу систем управління, що забезпечують максимальну швидкодію, $є$ надзвичайно актуальним.

Аналіз останніх досліджень і публікацій. В умовах сьогодення спектр наукових досягнень у сфері перетворення напруги є значним. Багато як зарубіжних, так і вітчизняних учених підійшли до вивчення питання перетворення напруги, а також іiі стабілізації.

В.А. Халіков та А.Г. Можаровський [2] розкрили принципи реалізації характеристики «вхідвихід» дискретного стабілізатора змінної напруги на основі трансформаторно-ключової виконавчої структури. Авторами наведено результати досліджень можливості побудови характеристики «вхід-вихід» дискретного стабілізатора змінної напруги, що має у своєму складі трансформаторно-ключову виконавчу структуру із двохобмотковим вольтододавчим трансформатором. Для двох типових структур доведено, що реалізувати характеристику з незмінними петлями гістерезису в усьому діапазоні зміни вхідних напруг неможливо. Показано, що під час роботи трансформатора в режимі вольтододавання петлі менші, ніж під час вольтовіднімання.

Нові методи побудови керованих імпульсних джерел електроживлення з виходом на змінному струмі дослідив В.І. Яськів [3]. У роботі на основі аналізу наявних методів побудови керованих імпульсних джерел електроживлення 3 виходом на змінному струмі запропоновано нову топологію таких джерел, яка базується на використанні високочастотних магнітних підсилювачів у ролі силових комутаційних елементів. Зроблено порівняння з існуючими аналогами. Наведено функціональну схему силової частини запропонованого керованого джерела електроживлення та описано принцип іiї роботи.

У [4] висвітлено засади теорії та методи аналізу й синтезу автоматичних електромеханотронних систем. Наведене дослідження містить широке коло питань із теорії лінійних неперервних та імпульсних систем автоматичного регулювання. Я.В. Щербак та К.Я. Івакіна розглянули моделювання динамічних ланок і автоматичних систем із перетворювачами електроенергії.

В.В. Божко [5] розробив швидкодіючу систему безконтактного захисту силового устаткування тягової підстанції постійного струму при коротких замиканнях у тяговій мережі, яка завдяки використанню паралельного вузла короткочасного струмообмеження, що підключається і відключається до вольтододаткового перетворювача, дозволяє не тільки обмежувати величину аварійного струму на рівні $1,2 \div 1,3$ від допустимого робочого струму в номінальному режимі, але у сукупності із використанням регулювання основного дванадцятипульсного випрямляча реалізувати майже бездугове відключення комутаційних апаратів та забезпечити м'якість пускових процесів. Ю.О. Семененко [6] також підійшов до розгляду питання застосування стабілізуючих силових активних фільтрів у сфері електропотягів.

К.К. Побєдаш та В.А. Святненко [7] розглянули однофазні і трифазні керовані та некеровані випрямлячі, згладжувальні фільтри та стабілізуючі пристрої, імпульсні перетворювачі постійної напруги, автономні інвертори та інвертори, ведені мережею, а також перетворювачі частоти.

Iз зарубіжних авторів варто відзначити: Xin Zhang, Xinbo Ruan, and Qing-Chang Zhong [8], Robert, S.B., Philip, T.K. [9], Mohammad Amin, Qing-Chang Zhong [10], K. Jo, J. Kim, D. Kim, C. Jang, and M. Sunwoo [11], Q.-C. Zhong and T. Hornik [12] та інших.

Проте, враховуючи описані наукові набутки за темою, питання дослідження стабілізуючого перетворювача напруги залишається відкритим та потребує детального опрацювання.

Постановка завдання. Мета статті - розкрити принципи дії стабілізуючого перетворювача напруги.

Виклад основного матеріалу дослідження. В умовах сучасного розвитку автономні джерела електроенергії набувають максимальної популярності. Однією з основних цілей створення автономних джерел електроенергії, що складаються 3 електричної машини і силового напівпровідникового перетворювача для автономних систем електропостачання, $є$ забезпечення споживача електроенергією, параметри якої відповідають стандартам якості [13]. Основними показниками якості автономних джерел електропостачання $€$ параметри вихідної напруги, які визначаються номінальними амплітудою і частотою напруги. 
Відхилення напруги живлення, струмів і навантажень - основна причина виходу з ладу дорогого устаткування. Тому стабілізація електричних параметрів перетворювальних джерел як ключового компонента систем автономного електропостачання $\epsilon$ актуальним завданням.

Для формування хвилі вихідної напруги за допомогою електрогенератора (ЕГ) найбільш перспективним методом регулювання вихідної напруги для широкодіапазонної зміни частоти обертання генератора і споживаної потужності $\epsilon$ регулювання напруги в обмотках збудження електрогенератора [8-10].

У цьому разі перетворювач напруги може мати кілька каналів стабілізації вихідної напруги:

- за допомогою ланцюга обмотки збудження постійного струму;

- за допомогою ланцюга обмотки збудження змінного струму;

- за допомогою схеми циклоконвертера.
Крім того, можна використовувати одночасно два або всі канали, що дає змогу точно змінювати відсоток амплітудної модуляції і стабілізувати вихідні електричні параметри.

Кожен із методів стабілізації вихідних параметрів може застосовуватися для зміни вихідної напруги перетворювача шляхом зміни кута управління напівпровідниковим перетворювачем, який знаходиться в ланцюзі якоря синхронного генератора. Спільне використання цих методів дає змогу підвищити точність управління і розширити діапазон швидкостей ведучого вала для одноканальної системи збудження генератора.

На рис. 1 наведена функціональна схема стабілізуючого перетворювача напруги, в якій вихідну напругу стабілізовано за допомогою ланцюга обмотки збудження постійного струму. Тут електрогенератор (ЕГ) є модуляційним і складається 3 двох електричних машин, розташованих в одному корпусі синхронного генератора $(\mathrm{CГ})$

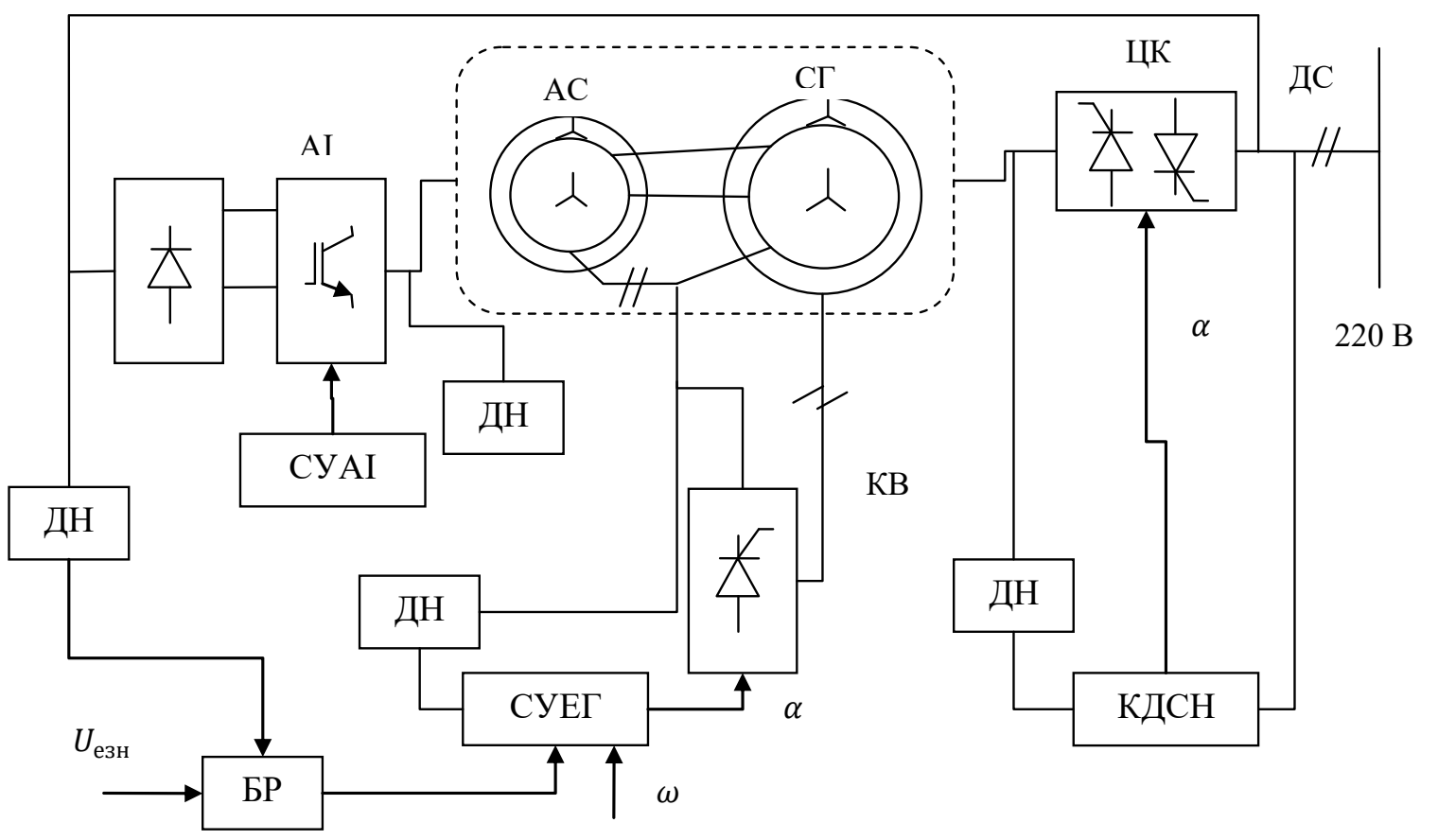

Рис. 1. Функціональна схема системи стабілізації параметрів електричної вихідної напруги за допомогою ланцюга обмотки збудження постійного струму

$U_{\text {ези }}$ - еталонне значення напруги

А3 - асинхронний збудник

AI-автономний інвертор

БР - блок обчислення різниць фаз

ДН-датчик напруги

ДС-датчик струму

$К B-$ керований випрямляч

КДСН - кероване джерело струму і напруги

СГ- синхронний генератор

СУАІ-система управління автономним інвертором

СУЕГ-система управління електричним генератором

ЦК - ииклоконвертер 
3 додатковою трифазною обмоткою збудження, намотаною на ротор, i без демпферної обмотки, без асинхронного збудника (АЗ). Генератор видає потужність на однофазний циклоконвертер (ЦК). Циклоконвертер має власну систему управління 3 постійними кутами запалювання $(\alpha)$ в режимі випрямляча й інвертора і працює як демодулятор вихідної напруги електрогенератора, а амплітудне значення вихідної напруги стабілізуючого перетворювача визначається електрогенератором, а не кутом запалювання циклоконвертера. Кут включення циклоконвертора формується залежно від сигналів датчика струму (ДС) і датчика напруги (ДН).

Система управління автономним інвертором (СУАІ) із широтно-імпульсною модуляцією (ШІМ) в цьому разі має постійний опорний сигнал частоти й амплітуди струму збудження асинхронного збудника, що не залежить від вихідних параметрів перетворювача напруги. Вхідними сигналами системи управління електричного генератора (СУЕГ) виступають швидкість ведучого валу $(\omega)$ й опорне значення напруги $\left(U_{e s н}\right)$ порівняно 3 поточним значенням амплітуди вихідної напруги (в різницевому блоці (БР)). Регулювання амплітуди вихідної напруги джерела автономного перетворювача здійснюється зміною кута включення керованого випрямляча (КВ), який живить ланцюг обмотки збудження постійного струму електрогенератора.
На рис. 2 наведена функціональна схема перетворювача напруги, в якому вихідна напруга стабілізується за допомогою ланцюга обмотки збудження змінного струму.

Тут вихідна напруга регулюється за допомогою автономного інвертора (AI), який живить ланцюг статора асинхронного збудника (АЗ). На відміну від попереднього способу, тут у ланцюзі обмотки збудження постійного струму встановлено некерований випрямляч $(\mathrm{HB})$.

На рис. 3 наведена функціональна схема перетворювача напруги, що являє собою комбінацію розглянутих вище систем стабілізації вихідних електричних параметрів.

В обмотці якоря синхронного генератора ЕРС наводиться від обмотки збудження постійного струму. Обмотка збудження синхронного генератора через керований випрямляч $\epsilon$ навантаженням для асинхронного збудника. Додатково трифазна обмотка збудження синхронного генератора намотана на ротор, що також $є$ навантаженням для асинхронного збудника. Сума двох ЕРС, наведених в обмотці якоря синхронного генератора, дорівнює результуючій ЕРС, амплітуда якої змінюється з частотою биття. У результаті вилучення вихідної напруги за допомогою циклоконвертера можна отримати незалежність частоти биття від частоти обертання валу генератора. Але тут необхідно, щоб кількість пар полюсів обмоток синхронного генератора була рівною сумі кількості

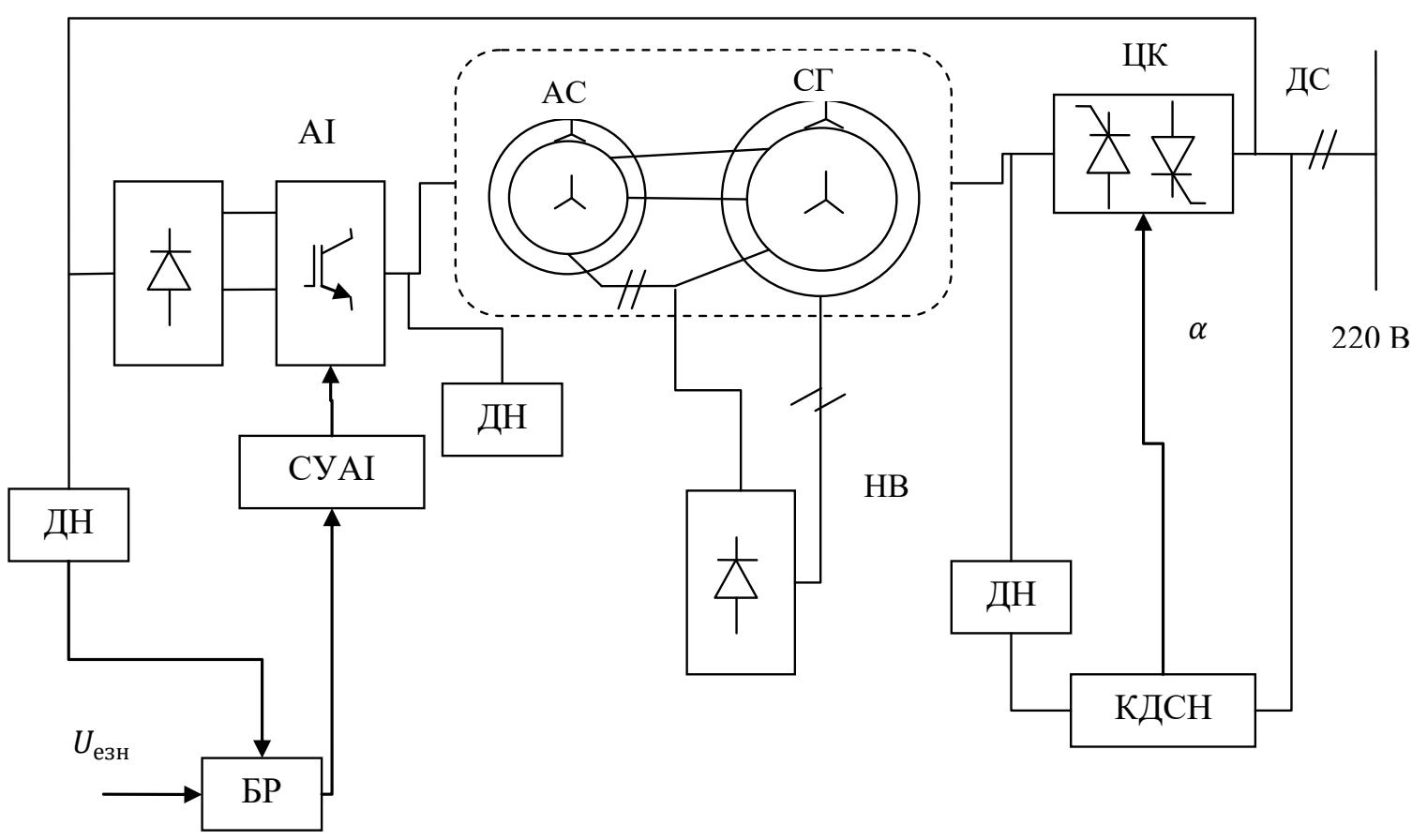

Рис. 2. Функціональна схема системи стабілізації параметрів електричної вихідної напруги за допомогою ланцюга обмотки збудження змінного струму

$H B$ - некерований випрямляч 


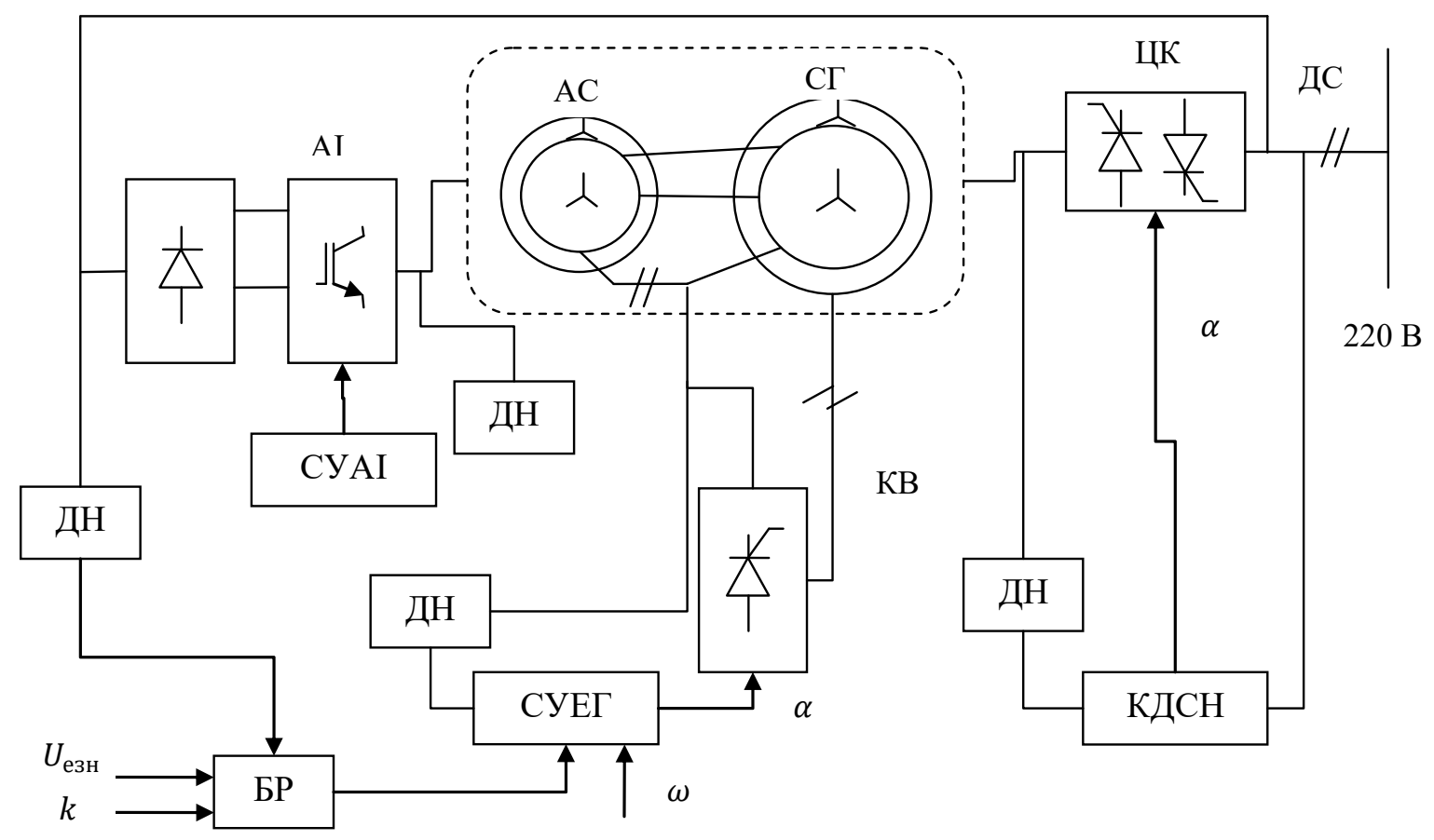

Рис. 3. Функціональна схема системи стабілізації параметрів електричної вихідної напруги комбінованого типу

пар полюсів обмоток асинхронного збудника i додаткової трифазної обмотки збудження синхронного генератора.

Висновки. У роботі досліджено принципи роботи стабілізуючих перетворювачів напруги 3 виведенням функціональних схем за трьома основними типами перетворювачів. Стабілізуючі перетворювачі напруги, побудовані за наведеними вище функціональними схемами (на рис. 1, 2, 3), дають змогу виводити трифазну систему модульованої напруги. Виділення моделюючої функції за допомогою циклоконвертера дає змогу отримати як вихідну напругу перетворювача однофазну напругу, близьку за формою до синусоїдальної хвилі. У цьому разі частота вихідної напруги буде дорівнювати половині частоти змінного струму збудження і не залежати від частоти обертання генератора.

\section{Список літератури:}

1. Аналогова схемотехніка. Київ: КПІ ім. Ігоря Сікорського, 2017. 177 с.

2. Халіков В.А., Можаровський А.Г. Реалізація характеристики вхід-вихід дискретного стабілізатора змінної напруги на основі трансформаторно-ключової виконавчої структури. Пр. Ін-ту електродинаміки НАН Украӥни. 2012. Вип. 31. С. 106-111.

3. Яськів В.І. Нові методи побудови керованих імпульсних джерел електроживлення з виходом на змінному струмі. Вимірювальна та обчислювальна техніка в технологічних прочесах. 2015. № 4. С. 92-96.

4. Щербак Я.В., Івакіна К.Я. Основи теорії автоматичного регулювання електромеханотронних систем : навч. посібник. Харків : ХНУМГ ім. О.М. Бекетова, 2019. 222 с.

5. Божко В.В. Стабілізуючі перетворювальні агрегати вольтододаткового типу підвищеної ефективності для тягового електропостачання постійного струму електрифікованих залізниць : автореф. дис ... канд. техн. наук : 05.22.09 / В.о. Нац. техн. ун-т «Харківський політехнічний інститут». Харків : [б.в.], 2011. $21 \mathrm{c}$.

6. Стабілізуючі силові активні фільтри для підвищення ефективності тягового електропостачання постійного струму : автореф. дис. ... канд. техн. наук : 05.22 .09 ; Харків. нац. ун-т міськ. госп-ва ім. О.М. Бекетова. Харків, 2017. 20 с.

7. Побєдаш К.К., Святненко В.А. Силові напівпровідникові прилади і перетворювачі електричної енергії: навч. посіб. Київ: КПІ ім. Ігоря Сікорського, 2017. 244 с.

8. Wang, Y., Ren, B., \& Zhong, Q.C. Bounded UDE-based controller for input constrained systems with uncertainties and disturbances. IEEE Transactions on Industrial Electronics. 2020. No. 68(2). P. 1560-1570.

9. Robert, S.B., Philip, T.K. IEEE Transactions on Power Electronics 28, 2013. P. 537-546. 
10. Amin M., \& Zhong, Q.C. Resynchronization of distributed generation based on the universal droop controller for seamless transfer between operation modes. IEEE Transactions on Industrial Electronics. 2019. No. 67(9). P. 7574-7582.

11. Jo K., Kim J., Kim D., Jang C., \& Sunwoo, M. Development of autonomous car-Part II: A case study on the implementation of an autonomous driving system based on distributed architecture. IEEE Transactions on Industrial Electronics. 2015. No. 62(8). P. 5119-5132.

12. Zhong Q.-C., Hornik T. Control of Power Inverters in Renewable Energy and Smart Grid Integration. Piscataway, NJ, USA: Wiley-IEEE Press, 2013.

13. ГОСТ 13109-97. Электрическая энергия. Совместимость технических средств. Нормы качества электрической энергии в системах электроснабжения общего назначения.

\section{Sydorenko O.I. STABILIZING CONVERTER AS THE BASIS OF THE SYSTEM OF STABILIZATION OF ELECTRIC OUTPUT VOLTAGE PARAMETERS}

The principles of operation of stabilizing voltage converters with derivation of functional circuits by three main types of converters are investigated. It is emphasized that the basic circuits of stabilizing voltage converters are step-down and step-up circuits. It is noted that when designing secondary power supplies for uninterruptible power supplies and autonomous power supply systems, regulation (stabilization) of the output voltage must be carried out in both of the above zones. The necessity of application of stabilization principles for autonomous power supply systems is given. It is proved that the most promising method of output voltage control for wide-range change of generator speed and power consumption is voltage regulation in the excitation windings of the generator. Output voltage stabilization channels are characterized and it is emphasized that it is possible to use two or all channels simultaneously, which allows to accurately change the percentage of amplitude modulation and stabilize the output electrical parameters. Three functional schemes of stabilization of parameters of electric output voltage with different types of current coming on stabilization are given: alternating, direct and combined. The components of each scheme are disclosed separately. Based on the analysis of functional circuits, it is noted that the difference between the rotation of the rotor and the supply winding of the asynchronous exciter from the autonomous inverter with pulse-width modulation is that the electromotive force is induced in the rotor winding of the asynchronous exciter. It is proved that as a result of extraction of output voltage by means of the cycloconverter it is possible to cancel dependence of frequency of beating on frequency of rotation of a shaft of the generator.

Key words: stabilizing converter, voltage, electricity, regulation, power supply, circuit, power supply. 